\title{
Economic growth and urban metamorphosis: A quarter century of transformations within the metropolitan area of Bucharest
}

\author{
Cristian Toșa \\ Technical University of Cluj-Napoca \\ cristian.tosa@infra.utcluj.ro
}

Hitomi Sato

Nagoya University

sato@trans.civil.nagoya-u.ac.jp

\author{
Andrei Mitrea \\ Ion Mincu University of Architecture \\ and Urban Planning \\ andrei.mitrea@uauim.ro
}

\author{
Tomio Miwa \\ Nagoya University \\ miwa@nagoya-u.jp
}

\section{Takayuki Morikawa}

Nagoya University

morikawa@nagoya-u.jp

\begin{abstract}
This paper concentrates explicitly on examining the structural and functional transformations occurring within the metropolitan area of Bucharest, resulting from sustained economic growth during the past quarter century, by conducting a time analysis, spanning the entire period since the fall of the communist regime in late 1989.

Cities in developed countries of Western Europe and Asia experienced rapid economic growth during the second half of the 20 th century and exhibited novel patterns of evolution in terms of urban form and associated functional characteristics. Lately, these patterns have become manifest in Bucharest as well. However, transformations in human, social, residential, and transportation supply capital are difficult to observe directly. Hence, our methodology concentrates on studying interactions between several proxies connected to economic development within the metropolitan area of Bucharest. This paper should be

\section{Article history:}

Received: May 29, 2017

Received in revised form:

October 30, 2017

Accepted: October 30, 2017

Available online: February 22, 2018

read as an exploratory study that buttresses the assumption that improved economic well-being, when accompanied by the transition between a centrally planned economy to a market economy, increases motorization rates, while at the same time triggering a sharp decline in the use of public transport and contributing to aggressive urban sprawl processes. Moreover, hopefully it will guide future research dedicated to forecasting urban expansion paths and their determinants. Hopefully, it also informs policy design intended to promote sustainable urban mobility and accessibility.
\end{abstract}

Keywords: Westernization, sustainable urban transportation, economic growth, urban sprawl, post-socialist city

Copyright 2018 Cristian Toșa, Andrei Mitrea, Hitomi Sato, Tomio Miwa \& Takayuki Morikawa http://dx.doi.org/10.5198/jtlu.2018.1242

ISSN: 1938-7849 | Licensed under the Creative Commons Attribution - Noncommercial License 4.0

The Journal of Transport and Land Use is the official journal of the World Society for Transport and Land Use (WSTLUR) and is published and sponsored by the University of Minnesota Center for Transportation Studies. 


\section{Introduction}

It is generally acknowledged that increasing levels of income are currently the main causes behind the growth in car ownership and urban sprawl. However, suburbanization was not caused initially by the growth in motorization, but by changes in the socio-economic context, such as increase in income, the diversification of the workforce, smaller households, and changes in lifestyle (Wegener, 1996). The collapse of the socialist bloc in 1990 exposed Central and Eastern European (CEE) countries to the global economy to varying degrees, thereby restructuring their internal markets and political-administrative structures, and bringing significant changes to their cities (Hegedüs, 2008).

Market forces that are active in land use are continuously reshaping cities, due to growing international connections and extensive domestic investments, and as a result enlarge the social and economic boundaries of human activities. Consequently, when sprawling residential areas are not serviced by adequate public transport systems, population mobility shifts towards car use, unavoidably leading to environmental problems (Jensen, 1999). Rapid motorization accompanied by urban sprawl and the decline in the use of public transport exerts a tremendous impact on energy demand, as well as negative effects on the environment.

In terms of overall urban density and use of energy in transport, Newman and Kenworthy (1991) plotted fuel consumption per capita against population densities in several large cities around the world, concluding that high-density urban areas are more energy-efficient than their low-density counterparts. This study has since been repeatedly confirmed, extended, and updated (Boquet, 2009; Doi \& Kurokawa, 2001; Schwanen, 2002; van de Coevering \& Schwanen, 2006).

Against this background, Hayashi (1996) developed a method to identify different stages of urbanization and economic development, by analyzing several components of the built environment and motorization, and then plotting transportation system performance and computing its environmental impact. Taniguchi, Murakawa, and Morita (1999) studied the relation between population density and transportation energy consumption in more than 60 Japanese cities, concluding that cities lacking railway transport accessibility have higher car usage.

Economic transformations of the 1990s in CCE have brought about significant changes in the way individuals travel and in the means by which goods are transported. Sharp increases in private motorization caused an overall re-orientation of modal preferences (Judge \& Kaminski, 1996), while national transport infrastructure (road and rail) aged rapidly, due to insufficient investment and maintenance over a prolonged period (Crass, 2004).

In this context, Berlin represents a special case, where the political and economic system has influenced several aspects of spatial configuration and urban transportation. The construction of the Berlin Wall in 1961 induced different patterns of development in the eastern and western halves of the city. When the Wall fell, in 1989, the eastern side of Berlin, which suffered physical and behavioral constraints during communism (Kloas, Kuhfeld, \& Kunert, 1998), was subjected to a sharp upheaval in transport demand. Motorization rate consequently grew by more than 30\% in East Berlin within a year and a half, while public transport ridership declined significantly until 1994, with subsequent urban sprawl becoming manifest (Bertaud, 2006; Wolf, 1994). By the beginning of the 21st century, Berlin, due to its dynamic spatial distribution of jobs and residential areas, had lost around 270,000 inhabitants to the suburbs and its hinterland (Miyamoto et al., 2004).

Nonetheless, following a period of continuing recovery, Berlin achieved less car transport and higher modal share for public transport and other sustainable modes. Kenworthy and Laube (1999) state that dependence on the privately-owned car along with declining transit in cities can, in fact, be avoided. Motorization growth and the consumption of transport energy appear to be sensitive to public policy 
through effective land-use planning, creation of and maintenance of transportation infrastructure, and service delivery policies directed towards non-motorized modes, as well as through economic policies that set higher prices for car ownership and use.

Despite the existence of a body of knowledge amassed from published works on post-socialist societies (Enyedi, 1996; Hamilton, Andrews, \& Pichler-Milanović, 2005; Stanilov, 2007; Tsenkova \& Nedovic-Budic, 2006), as well as exploratory scientific publications on Eastern Europe the over the past 25 years (Bertaud, 2006; Hegedüs, Tosics, \& Mayo, 1996; Suditu, Dumitrache, Vîrdol, \& Vâlceanu, 2014), Hegedüs (2008) noted that no new theory has been developed on post-socialist cities. To better understand the paths that developed metropolises followed in the stage of fast economic growth, Hayashi (1996) states that historical comparisons could be used to create empirical forecast scenarios for developing metropolises to better accommodate future sustainable development paths and assure a pleasant living environment.

In response to current developments in the field, this research exercise intends to add to the accumulated knowledge the experience of the Romanian communist past and its transitional path towards a democracy based on a functional market economy, by merging elements that concur around the economic development that has driven society towards westernization.

Hence, the structure of this paper is as follows: The rest of the current section sets forth the events of Romania's political history that precede the timeframe of our analysis, in order to better grasp the transformations occurring after 1989. The research strategy is subsequently shown and explained, which is then followed by a section outlining the aims of the research exercise. The rest of the paper represents the analysis proper. The concluding section summarizes the findings and illustrates some future avenues of research.

\subsection{A brief history of socialist Romania}

To fully grasp the changes pervading the Romanian transition period of the 1990s, it is necessary to review a few key aspects of the political, socio-economic, and demographic legacy inherited after fifty years of communism. Hence, the following few paragraphs will briefly set out the course of events after occurring after World War II, while explicitly concentrating upon the aims of this paper.

Thus, after seizing power in 1946, the Romanian Communist Party embarked upon a series of structural reforms, deemed necessary in order to transform the country into a highly industrialized state. Nationalization quickly ensued, with production and retail almost completely transferred to the state. Domestic consumption subsequently dropped to historical lows, with cars, for instance, owned solely by institutions.

Nevertheless, by 1965, when Nicolae Ceaușescu assumed office, Romania was already witnessing a period of relative liberalization, in tune with most countries of the socialist block. Capitalizing upon a favorable international context, Ceaușescu heralded an era of emancipation from Soviet control that was accompanied by renewed interest in the domestic consumer market. Households and private individuals could now own cars, albeit at some considerable cost and after prolonged waiting times.

Concomitantly, industrialization was already well underway throughout the country, increasingly financed through international loans. All the major cities were endowed with heavy industrial platforms, which, in turn, prompted massive waves of migration from rural areas, where the collectivization rendered most of the rural workforce unemployed. The new migrants received housing within the newly built housing estates at the fringes of large cities, in an atmosphere of tight controls on residence and housing production (Suditu et al., 2014).

Massive industrialization led to a $40 \%$ decrease in the rural population during the communist regime (Scrieciu, 2011), a staggering amount that points towards a thinly veiled process of social engi- 
neering (cf. Cook, 2001). The magnitude of this experiment rapidly becomes apparent when considering the effects of the natalist policies undertaken by the communist regime. Hence, a decree prohibiting abortions, issued in 1967, immediately produced a 92\% increase in birth rates (Pop-Elecheș, 2006). Within the first few years, more than 400,000 babies were being born each year, thereby placing a strain on nurseries, kindergartens, and schools. In the years that followed, they would place a heavy toll on employment and housing.

The energy crisis of the 1970s brought drastic austerity measures, which became manifest in 1982 . They were aggravated further by the regime's disproportionate efforts to repay the foreign debt acquired over the years. Basic food, electricity, hot water, and gasoline were all rationed. Each automobile was entitled to 20 liters of gasoline per month and travel restrictions were imposed (Ofrim, 2013).

Romania remained isolated internationally until December 1989, when the revolution toppled the communist regime, thereby ending the country's socialist period. From then on, Romania officially embarked upon the strenuous path of transforming into a democracy based on a functional market economy (Cook, 2001). However, this transformation never fully delivered (Gallagher, 2005, 2009). Nonetheless, after 1989, people were determined to achieve a better quality of life, by taking the Western civilization as their model, albeit rather indiscriminately.

\section{Research strategy}

In this research exercise, we explore interactions among the proxies of the three types of capital that shaped the continuous economic growth experienced by Romania for the past 26 years. Hence, we shall focus on human and social capital, housing and residential capital, as well as transportation supply capital (cf. Figure 1). Our study area is confined to the city of Bucharest and its environs, but no farther than the fringes of the county of Ilfov. A few explanations are here due.

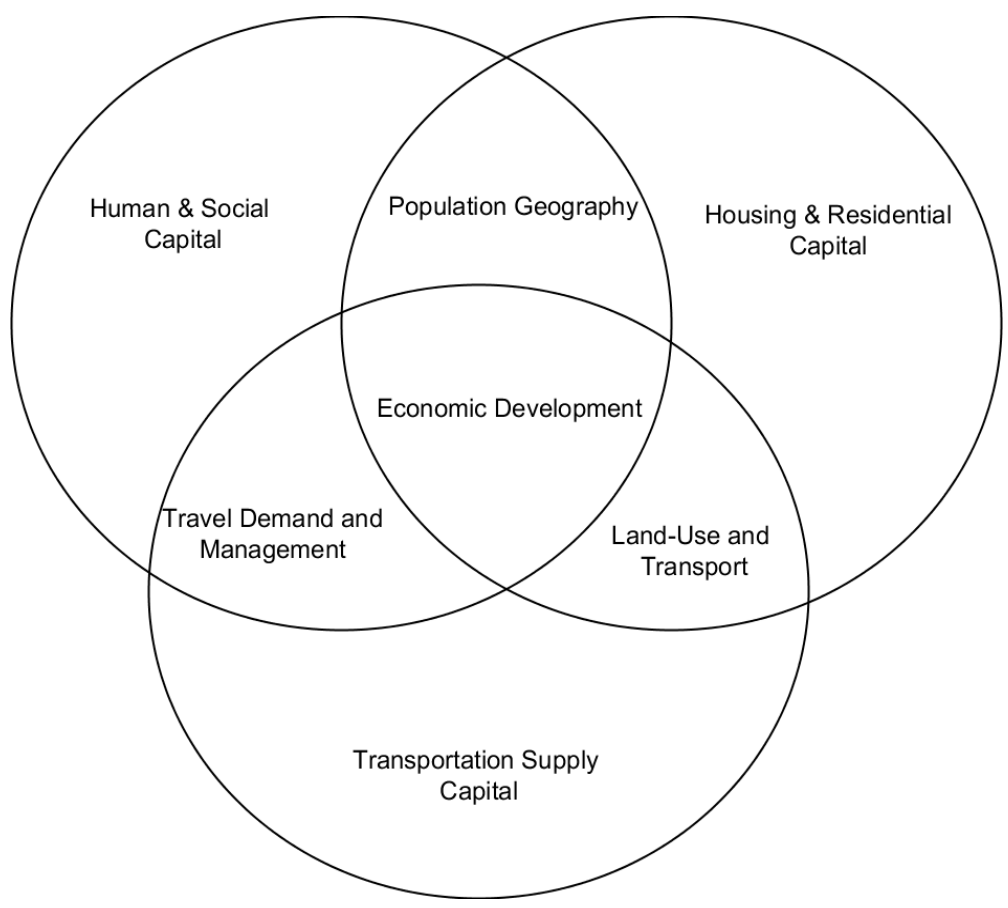

Figure 1: Research strategy

Source: Authors. 
Firstly, the built environment capital, such as housing and transportation supply capital, is subject to continuous transformations, which start from the planning stage, and continue throughout their entire lifespans (Wegener, 2004). Transportation networks are among the most permanent elements of the built environment within cities, usually suffering only very slow changes over time. They are followed by residential and non-residential buildings, which are more sensitive to changes within the social and economic fabrics of the city. Given the current volatility of the labor market, it comes as no surprise then that interactions among spatially distributed human activities, such as travel, transport of goods, as well as delivery of services can be, and usually are, instantaneous. However, when trying to contemplate the slow changes in infrastructure alongside the constant shifts in activity distributions, one is forced to work with proxies.

Secondly, well-being and aggregate societal wealth are influenced by a host of structural factors (Botzen, 2016), institutional factors, and economic factors (Barro, 2001; Barro \& Sala-i Martin, 2004), whose exact interactions are not fully understood. Against this background, human capital becomes prone to changes in individual skills and knowledge, which somehow emerge from these interactions. Human capital therefore forms a significant link between economic and demographic change (Mincer, 1984), standing as a focal point for development and sustainability studies (Mulder, Constanza, \& Erickson, 2006), as well as for quality of life studies (Kubík, 2010; Vemuri \& Costanza, 2006; Riboud, 2016).

When switching to a planning perspective, one is bound to notice that the majority of studies concentrating upon urban design trends and their influence on travel demand, topics that gained popularity in the 1990s (Cervero \& Kockelman, 1997), are mostly confined to the United States. Europe lagged a bit behind. Furthermore, Schwanen (2002) argued that the transfer of US findings to the European context would be questionable. Against this background, van de Coevering and Schwanen (2006) subsequently focused their attention solely upon Europe, thereby confirming the correspondence between urban form and travel behavior, by using a sample of European cities. However, due to differences between land-use and travel patterns across regions, Schwanen (2002) supported the idea that future research should focus on similar aspects of travel behavior in Southern Europe and the former communist countries in Eastern Europe. In response to these findings, we conducted our own exercise in assessing the transformations throughout the entire transition period, in order to obtain a comprehensive overview of the Bucharest-Ilfov metropolitan workings.

Nonetheless, the reader should bear in mind that the approach focuses on an aggregate level of analysis, i.e. on administrative areas, in such a way that certain proxies of the capital triad considered above may vary between territorial scales within the study area. Granularity is always a decisive factor in constructing research, and we must admit upfront that some proxies might have been more suitably measured on a more discrete level, such as the neighborhood. Unfortunately, such data is almost impossible to get by. In addition, the exploratory nature of this exercise does not allow for correlations or regression procedures to reveal the underlying factors or mechanisms, by which the proxies may interact and influence each other. That being said, a note on data collection is due: We obtained most data sets from the online database of the Romanian Institute of Statistics (Institutul Naţional de Statistică/INS), Eurostat, and the World Bank, as well as from the censuses of 2002 and 2011. We complemented them by recent population data and the corresponding data on the built environment from the Romanian company SC Micromapper SRL. These additional data sets were processed with QuantumGIS, version 2.14.4 (QGIS Development Team, 2013). 


\section{Bucharest: A changing city}

\subsection{The general layout}

Bucharest is the largest city in Romania, serving as its capital since 1862. It lies in the extreme southeastern part of the country, within the confines of Ilfov County (Figure 2, (a) and (b)). From an academic perspective, Bucharest started featuring more prominently within the international literature during the communist period, when Turnock (1990) began examining its evolution and expansion after World War II, in a period when thorough redevelopment efforts came to fruition. Needless to say, the forces shaping socialist cities were quite different from the ones affecting cities evolving within market economies. Hence, the allocation of industrial and residential land use was mostly conducted according to administrative decisions, and was based on input minimization, rather than value maximization (Kornai, 1992).

Nae and Turnock (2011) later analyzed the post-communist evolution of Bucharest, with an emphasis on the changes in the urban landscape within the city center and the outer suburban areas. Their study revealed a tortuous transition from heavy industry to retail. Without a clear vision from the authorities on how a 21st-century city should behave, both authors urged for more effective regulation and investments in the public transport system, in order to improve sustainable spatial connections between the urban core and the sprawling suburban settlements.

More recent research, conducted by Simion and Nistor (2012), demonstrates that Bucharest is undergoing a process of uncontrolled suburbanization. Massive inflows of capital and investment are generating economic growth, which, in turn, triggers the conversion of rural land into residential, commercial, and industrial use (Irwin, Isserman, Kilkenny, \& Partridge, 2010). With poor and ineffective regulation, the direct hinterland of Bucharest thus rapidly loses its available land reserves. Against this background, a plethora of industrial and service activities have relocated to suburban areas. Apart from the beneficial influence on tax revenue, they have also triggered successive waves of new residential or office buildings, which most of the time lack integration with municipal service networks, as will become poignantly clear in the sections that follow.
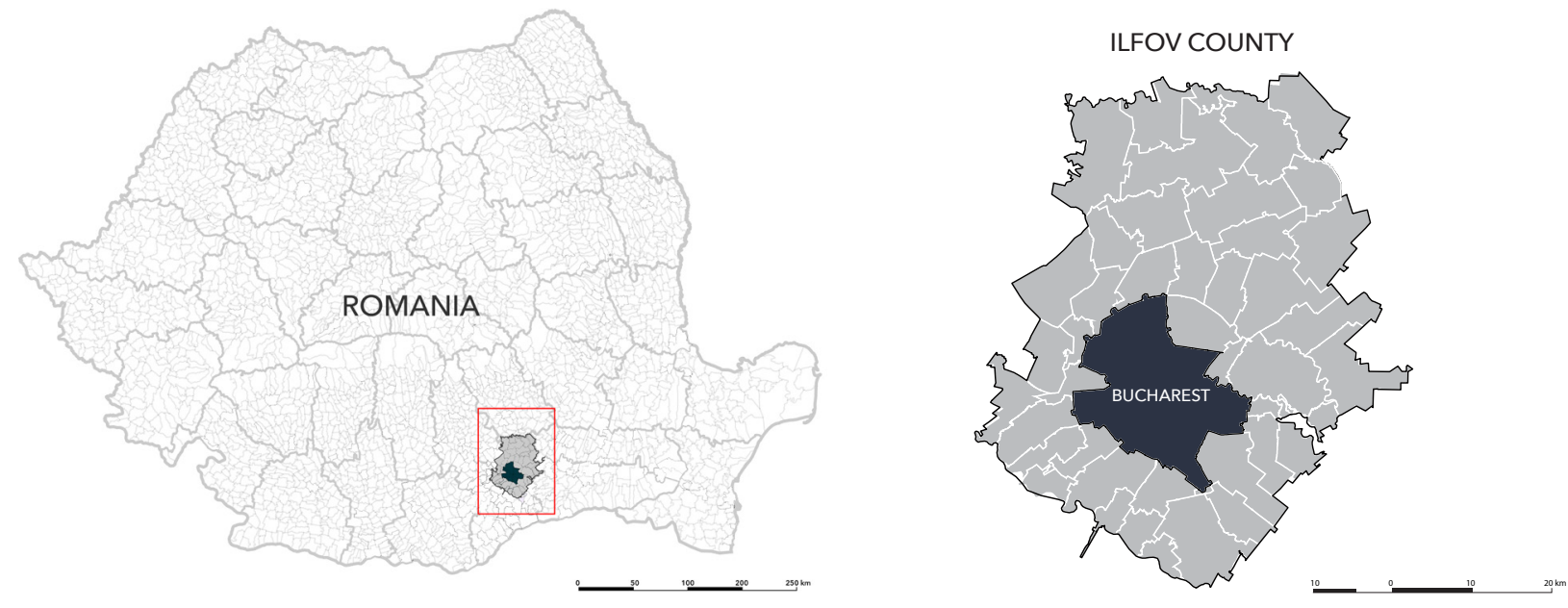

Figure 2: Study area location overview (a) and administrative layout (b) Source: Authors, based on Open Street Map (OSM) data. 
Hence, even though Romania has experienced a quite consistent period of economic growth between the years of 1999 and 2008 (Benedek \& Veress, 2013), Bucharest became one of the very few noticeable beneficiaries of this newly found wealth. This image turned out to be consistent throughout the entire CEE, with capital cities being the primary recipients of increasing levels of economic development.

The main reasons behind this state of affairs are preferential access to financial markets, as well as the high priorities they receive within national policies (Hegedüs, 2008). Nevertheless, a direct result of this rather fortunate prime mover advantage is an increasing gap between these metropolitan areas and the rest of the country. To illustrate this unequal development accurately, it suffices to mention that the gross regional product (GRP) per capita in Bucharest is now higher than the EU average and is triple the Romanian average (Ionescu-Heroiu et al., 2013b).

To put these figures into context, Figure 3 shows the change in gross domestic product (GDP) per capita in purchasing power standard (PPS) dollars for the Bucharest-Ilfov area and Romania, compared with the European average for the 28-member states. The illustration is marked by two pivotal years: 2004, when Romania joined the North Atlantic Treaty Organization (NATO), and 2007, when it joined the European Union (EU). These two rather exceptional moments have altered foreign investment strategies significantly, especially for investors looking for business opportunities in Bucharest.

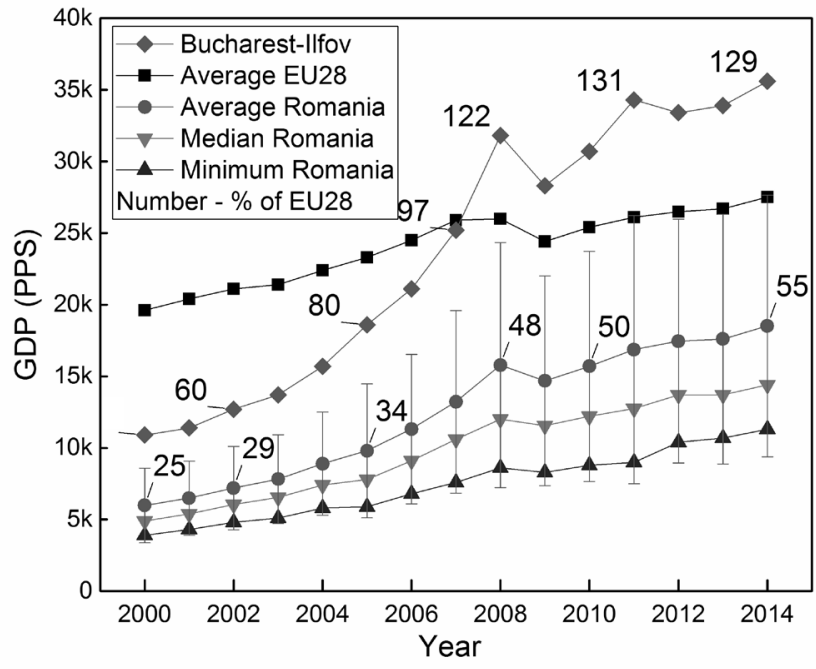

Figure 3: Change in PPS\$ GDP per capita

Source: INS and World Bank

In a wider European context, the European Commission (EC) has promoted a series of best-practice initiatives in the field of urban mobility, such as the Citizens' Network (EC, 1996), while at the same time focusing on sustainable development strategies, with the White Paper (EC, 2001) and the Green Paper, respectively (EC, 2007). Furthermore, the EC has enacted an Urban Mobility Package, which foresees procedures and financial support mechanisms for increasing competitiveness and resource-efficient transport systems within urban areas and their hinterlands (EC, 2013). Thus, 26 years after the fall of the communist regime in 1989, it became mandatory for local authorities to conduct surveys and to develop sustainable urban mobility plans (SUMP), in order to be eligible for further EU funding. The SUMP for the Bucharest-Ilfov Region (Avensa Consulting \& ROM Transportation Engineering, 2015) was released in December 2015 for public consultation, the plan being one of the eight SUMPs 
that were dedicated to Romania's major urban growth poles. The strategic priorities advanced within this particular SUMP were intended to offset the unfortunate Western experience of rapid growth in motorization and urban sprawl. The plan therefore proposed scenarios for boosting viable public transport alongside orderly spatial development. Nonetheless, its effects are slow to take hold and make an impact on the city.

It becomes therefore necessary to take a closer look at the three measures of transportation geography, as a blend between the items of the capital triad: population geography, land-use and transport, and transportation demand and management.

\subsection{Population geography}

In this section, we shall take a closer look at the evolution of human capital within the Bucharest-Ilfov Region. More precisely, we shall examine age and gender groups, as well as the occupational composition within the population. This analysis will be followed by the spatial mobility patterns expressed within the study area.

It is important to note that CEE societies have been affected by the demographic transition to a different extent than their Western counterparts. Hence, while socialist natalist policies have temporarily offset the effects of the demographic transition, the adjustment towards the market economy has been accompanied by population shrinkage and ageing, mostly due to the expansion of urban areas, their associated costs of living and rising time costs, as well as the growth in number of years dedicated to education (Mincer, 1984). These effects touch upon the very core of our research approach, and are consistent with the pressures exerted on the built environment and human capital.

Several studies have been conducted on the topic of ageing in Romania, most of them dealing with social and financial issues. From the perspective of the transportation system, population ageing may exert an impact both on its performance and on its further development (Coughlin \& Tompkins, 2009; Ryser \& Halseth, 2012). Mobility for the elders is most likely no less significant than that of their younger and economically active counterparts (van den Berg, Arentze, \& Timmermans, 2011), and increasing travel demand for senior citizens have already been forecasted (Coughlin \& Lacombe, 1997). In the same vein, Rosenbloom (2010) has asserted the need for a new policy window in terms of mobility options for rapidly ageing and increasingly diverse populations.

As stated previously, Romania experienced a baby boom starting in the late 1960s, which can easily be seen in the population pyramids for Bucharest and Ilfov within the age cohorts that are between 30 and 45 years old (cf. Figure 4). The demographic evolution from 2002 to 2011 indicates a process of ageing that will manifest itself for decades to come. Hence, the cohort born between 1967 and 1971 will reach the age of 50 between the years 2017 and 2021, shortly afterwards turning into a generation of retired people who will exert pressure on public services in order to satisfy their needs for social welfare (Ciumara, 2014). This particular generation, due to its disproportionate size, has had to face various challenges in the educational system and labor market.

After 1990 however, due to the negative birth rate and increased migration, Romania's population decreased continuously. Differences in age cohorts between rural and urban populations deepened (Jemna, Pintilescu, \& Turturean, 2010). With no barriers to changes in residence, a massive rural-urban migration ensued after the fall of the communist regime (Hegedüs et al., 1996). As a result, the predominant urban age cohort within the next decade is the one between 45 and 55 .

We do not have detailed information on the occupational structure or the income distribution among the population. However, we assume that their present market behavior and the travel patterns that they have been accustomed to during the past 25 years will most likely continue. Research in this field is scarce, and therefore poses some serious challenges to policy makers. 

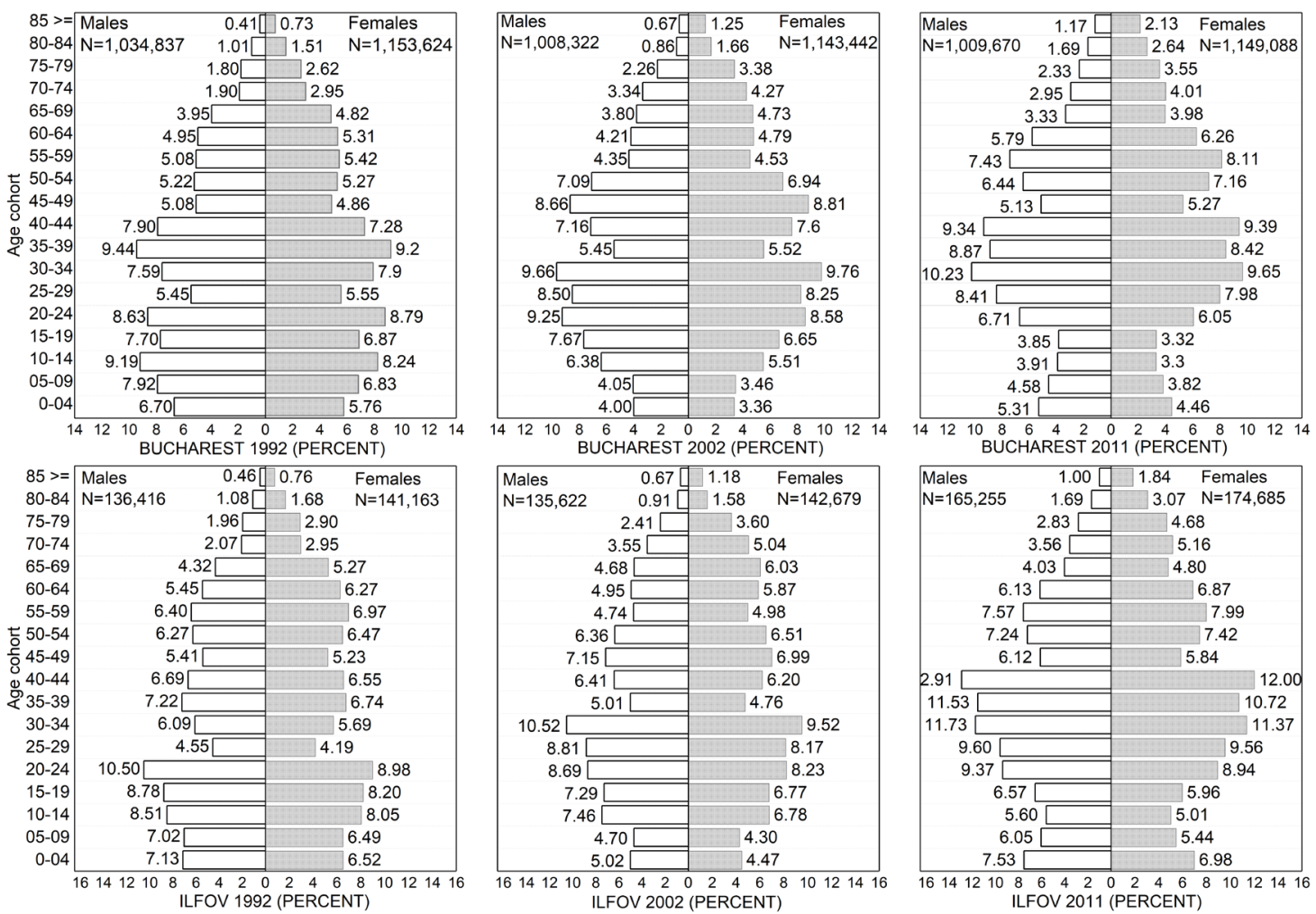

Figure 4: The evolution of the population pyramids within the Bucharest-Ilfov area Source: Census data (INS)

Figure 4 shows that Bucharest exhibits a relative consistency among age cohorts for consecutive censuses, with some slight increases due to in-migration. By population mobility, we understand the net difference between in-migrants and out-migrants, without considering changes in household location within the same administrative unit. After the 2011 census we notice a skyrocketing amount of outmigration for Bucharest and in-migration for Ilfov (cf. Figure 5), where people aged 30 to 45 appear to dominate the population pyramids.

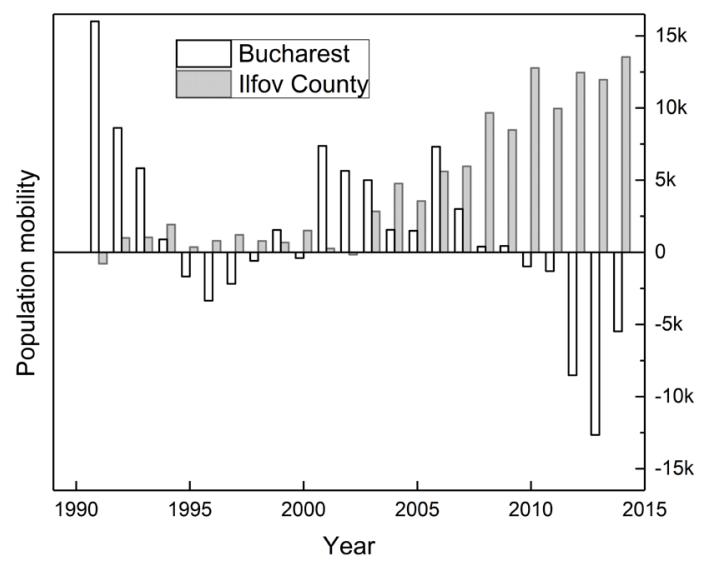

Figure 5: Population gains and losses for Bucharest and Ilfov County

Source: Census data (INS) 
Being at the peak of their professional career, people over 35 years old tend to earn more than the other age cohorts (Ciumara, 2014), thus driving them and their families to accessible housing at the fringes of Bucharest. Additionally, their households may have comparatively more members. We can therefore assume that they can afford to live further away and commute by their own personal means of transport. Petre (2008) referred to this group as active migrants, as they change their residential location, but their workplace and their urban lifestyle remain unaltered. The sociological profile of the active migrants in the new peri-urban areas of Bucharest describes them as families belonging to an emerging middle class, driven by some degree of consciousness towards the natural environment, while at the same time rejecting the old city lifestyle and communist patterns of habitation (Șoaită, 2014).

Table 1 shows the evolution of occupational structures across Bucharest and Ilfov. The homogeneous urban proletariat and professional groups from the communist period suffered severe changes, as a result of the restructuring processes of large industrial platforms. There has obviously been a transition from a working-class society towards a service-based one, but also a spatial migration of the workforce towards more economically attractive locations at the fringes of Bucharest.

Table 1: Evolution in the structure of the employed population

\begin{tabular}{|l|c|c|c|c|c|c|}
\hline \multirow{2}{*}{ International Standard Classification of Occupations } & \multicolumn{2}{|c|}{ Bucharest-Ilfov } & \multicolumn{2}{|c|}{ Ilfov County } & \multicolumn{2}{c|}{ Bucharest } \\
\cline { 2 - 7 } & 2002 & 2011 & 2002 & 2011 & 2002 & 2011 \\
\cline { 2 - 7 } & $\%$ & $\%$ & $\%$ & $\%$ & $\%$ & $\%$ \\
\hline Managers & 8.31 & 5.89 & 4.06 & 5.01 & 8.83 & 6.05 \\
\hline Professionals & 19.49 & 29.68 & 4.04 & 16.2 & 21.36 & 32.18 \\
\hline Technicians and associate professionals & 15.63 & 15.06 & 9.39 & 11.62 & 16.38 & 15.7 \\
\hline Clerical support workers & 8.64 & 6.81 & 6.23 & 5 & 8.93 & 7.15 \\
\hline Service and sales workers & 11.14 & 16.66 & 12.42 & 18.5 & 10.99 & 16.32 \\
\hline Skilled agricultural, forestry, and fishery workers & 0.98 & 2.73 & 7.31 & 12.45 & 0.21 & 0.93 \\
\hline Craft and related trades workers & 19.11 & 10.43 & 26.09 & 11.77 & 18.26 & 10.18 \\
\hline Plant and machine operators and assemblers & 9.38 & 7.04 & 13.99 & 9.5 & 8.82 & 6.58 \\
\hline Elementary occupations & 7.08 & 5.69 & 15.5 & 9.96 & 6.06 & 4.9 \\
\hline
\end{tabular}

Source: Census data (INS)

The early stage of economic liberalization is well documented by Dostie and Sahn (2006), who focus on the role of the social safety nets within the labor market. In Romania, the 1990s were characterized by a high level of unemployment, where many workers were not able to adapt to the new labor market and to its predominantly urban rules (Balint, 2013). Some were forced, while others preferred to leave Bucharest and return to their places of origin (Suditu et al., 2014).

While human capital was adapting to the incipient market economy, the Bucharest-Ilfov Region witnessed a visible increase in foreign direct investment, thereby accumulating far greater shares of human capital than any other growth pole in Romania (cf. Popescu, 2012). A more in-depth analysis will most likely unearth the main factors contributing to economic growth within the Romanian growth poles, surpassing the somewhat pedestrian findings that expenditure in research and development is an important effect of the generation of higher productivity and the competitiveness of human capital (cf. Bere, Otoiu, \& Burcezan, 2014). 


\subsection{Land use and transport}

Having seen how human capital has evolved during the transition period, our analysis will now show the spatial evolution of population density, when viewed as a direct consequence of urban sprawl and residential mobility at a metropolitan level. When accounting for GDP per capita and the Human Development Index (HDI), a study on spatial differentiation of economic development carried out on a regional scale in Romania, found a highly developed cluster region around Bucharest, which pointed to a severe case of polarization (Benedek, 2015). Furthermore, when accounting for the specific local expansion of social and economic boundaries of human activities, new residential developments tended to reflect socio-professional transformations, as well as an inconsistency or lack of public policies in the field of housing (Suditu et al., 2014).

Hence, gentrification in Bucharest during the transition period was characterized by many illegal transfers of property rights within the city center, especially when it came to the question of nationalized houses (Chelcea, 2006). Their subsequent trade on the real estate market may very well have caused an increase in the costs of living, as well as a rise in land prices (cf. Ionescu-Heroiu et al., 2013a). In addition, the reallocation of land, situated mainly in the vicinity of Bucharest, for new housing estates or for industrial and commercial units was often not accompanied by adequate infrastructure provision (Grădinaru et al., 2013; Grigorescu et al., 2012).

Switching briefly to a comparative perspective, it is interesting to note that Buckley and Mini (2000) compared the levels of economic development across Eastern Europe against developed countries around the world, with the aim of revealing the forced urbanization processes necessary to sustain the massive industrialization waves that permeated the postwar period. Their findings show that for the same levels of GDP per capita, larger proportions of the population lived in an urban environment in Eastern European economies than in the rest of the developed world. Hence, during the switch to market economies after 1990, former communist countries witnessed urban shrinkage and reverse migration away from the former industrial centers, where industries had gone into bankruptcy (IonescuHeroiu et al., 2013b). While Romania's population is now smaller by 4 million people than it was in 1990, due to declines in the birth rate and external migration, the suburbs around major Romanian cities have gained around 300,000 new inhabitants (Ionescu-Heroiu et al., 2013a).

The same observation applies to Bucharest as well. As we shall see, the population of Bucharest is decreasing at a slower rate than those of other major Romanian metropolitan areas (Nae \& Turnock, 2011). Hence, the city proper has lost $2.18 \%$ of its population between 2002 and 2011, that is, some 42,000 people. Nonetheless, when adding Ilfov to the equation, the picture changes: Taken together, Bucharest and its direct hinterland have recorded an annual increase in population at an average rate of $0.32 \%$ per year, during the same period. People started to move away from the city, most likely as a psychological response against the perceived densities of the former socialist times. Companies have duly followed suit, searching for lower taxes and easier access. The data is shown in Figure 5, which illustrates the accelerated out-migration for Bucharest and in-migration for Ilfov County. Some of the adjacent municipalities have therefore registered an increase in population during this period, shown in Figure 6, with some of them receiving city status. 


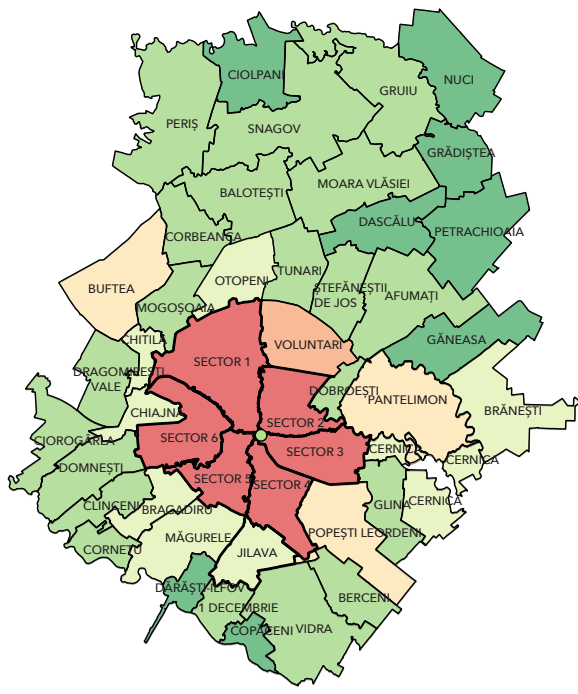

Population by Administrative Units. Bucharest-Ilfov Region

Legend

○ City Center

Administrative Units Bucharest

$\square$ Administrative Units llfov

Population

$\square$ 5,000

$5,000-10,000$

$10,000-20,000$

$20,000-30,000$

$30,000-50,000$

$>50,000$

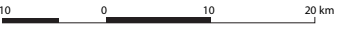

Figure 6: The population of Bucharest and Ilfov in 2011

Source: Authors, based on Open Street Map (OSM) and census data (INS).

Delving into more detail, Figure 7 reveals the percentage changes in registered population within the administrative areas of Bucharest and Ilfov between 2002 and 2011. The municipalities bordering Bucharest have gained more than 65,000 people. In total, Ilfov has grown by more than 85,000 people, from 303,254 inhabitants in 2002, to 388,738 inhabitants in 2011. Similar to what Western European cities have experienced during their growth phases during the 20th century, our analysis reveals that more than $76 \%$ of the growth in Ilfov County's population was registered at the outskirts of Bucharest.

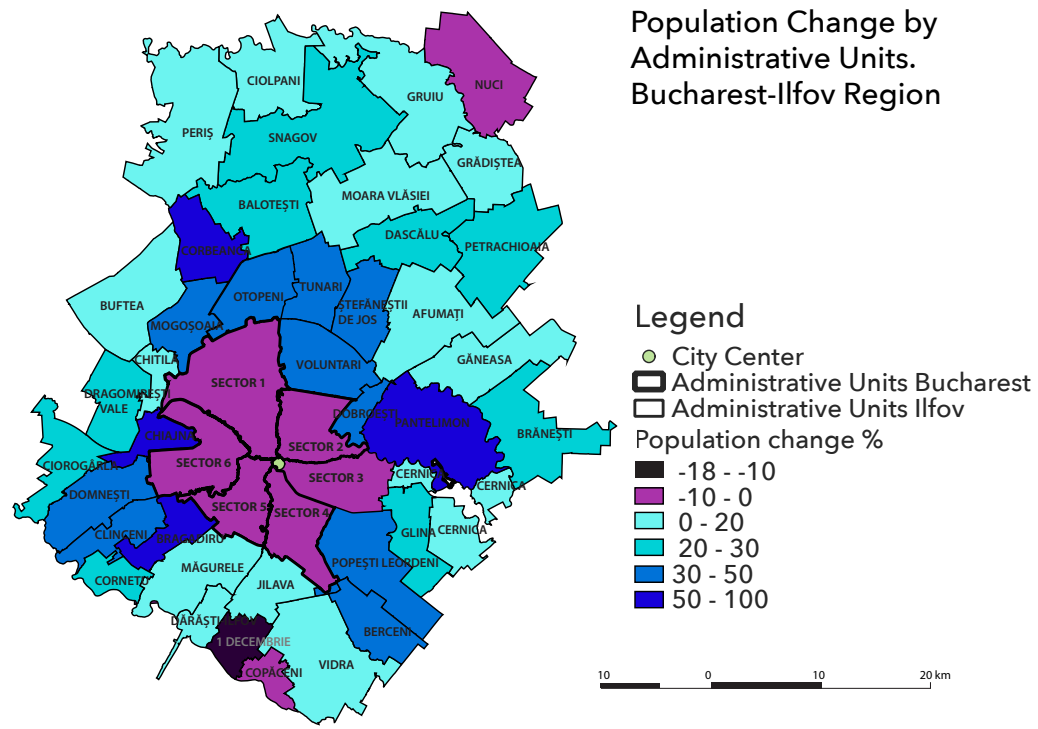

Figure 7: Population changes in Bucharest and Ilfov (2002-2011)

Source: Authors, based on OSM and census data (INS). 
Inheriting an urban form shaped by years of centralized planning, the population in Bucharest is distributed along a positively sloped linear function up until five or six kilometers away from the historic center (cf. Figure $8 \mathrm{~b}$ ). To complete the picture, in figure $8 \mathrm{a}$ we computed population density in a square grid network with a cell size of $1 \mathrm{~km} 2$. It is interesting to note that higher densities occur about three kilometers outside the city center. They are the result of forced rural-to-urban migration that was meant to provide the necessary workforce for the heavy industrialization program of the 1970s. Hence, whereas former socialist cities exhibit positively sloped population curves, their Western counterparts usually display negatively sloped curves. This phenomenon was described by Bertaud (2006) in his study on post-communist cities, and seems to be one of the most striking particularities of former socialist cities.

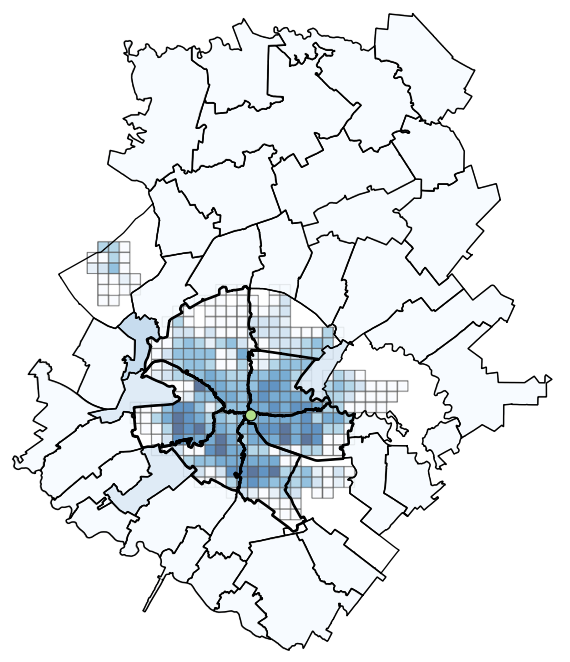

Population Density.

Bucharest-Ilfov Region

Legend

- City Center

Administrative Units Bucharest

$\square$ Administrative Units llfov

Population density (inh/sqkm)

$\square 0-500$

$500-1,000$

$1,000-2,000$

$2,000-5,000$

$5,000-10,000$

$10,000-20,000$

$20,000-30,000$

$30,000-50,000$

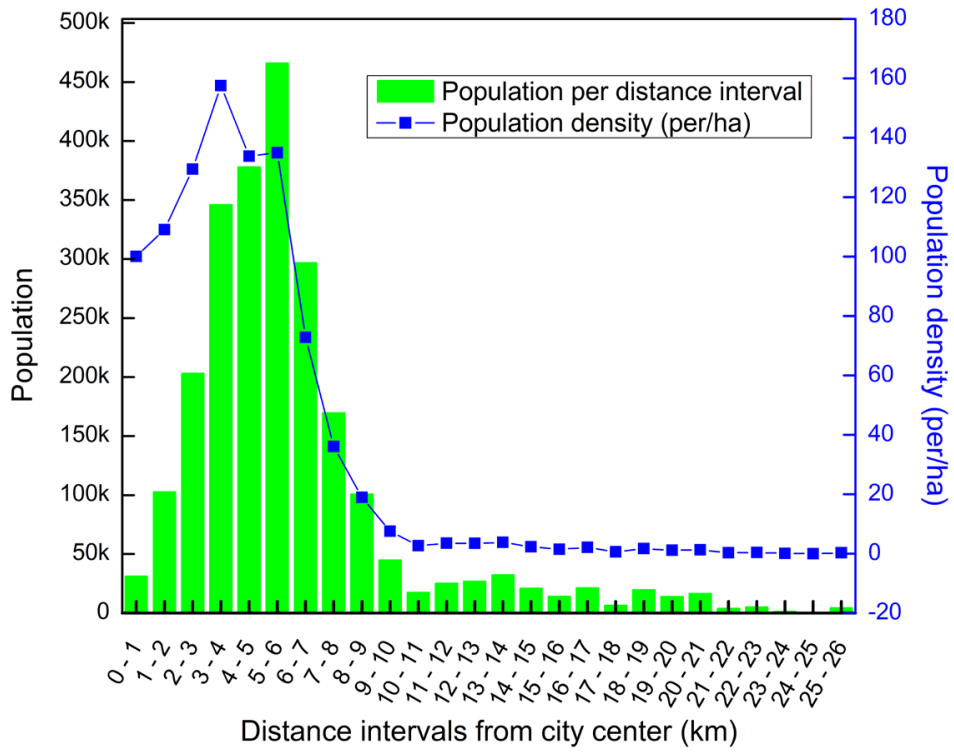

Figure 8: Population density (a) and population distribution (b) in Bucharest and Ilfov

Source: Authors, based on OSM and census data (INS).

\subsection{Transportation demand and management}

Within any economic system, a set of activities occurring in a region generates movements that must be 
supported by a transport system. Without a properly designed, upgraded, and adapted transport supply, these movements generate frictions and incur great costs. However, if supply exceeds demand, travel times are stable and predictable. Unfortunately, due to technological changes, unexpected socio-economic changes and improper forecasting, the growth in derived demand from individuals, groups, and industries, leads very often to congestion, reduction in transport safety, and the degradation of transport infrastructure. At the same time, this process raises concerns about public health and environmental degradation (Rodrigue, Comtois, \& Slack, 2017).

Against this background, the following paragraphs deal with the interaction between travel demand and supply in the Bucharest-Ilfov Region. This interaction has caused visible changes within the transportation system, such as a rebalance in modal share overtime, which was triggered by the rise in motorization rates countrywide, but especially in the Bucharest-Ilfov Region (cf. Figure 9). There is, however, no detailed public data is available for the period 1996-2002.

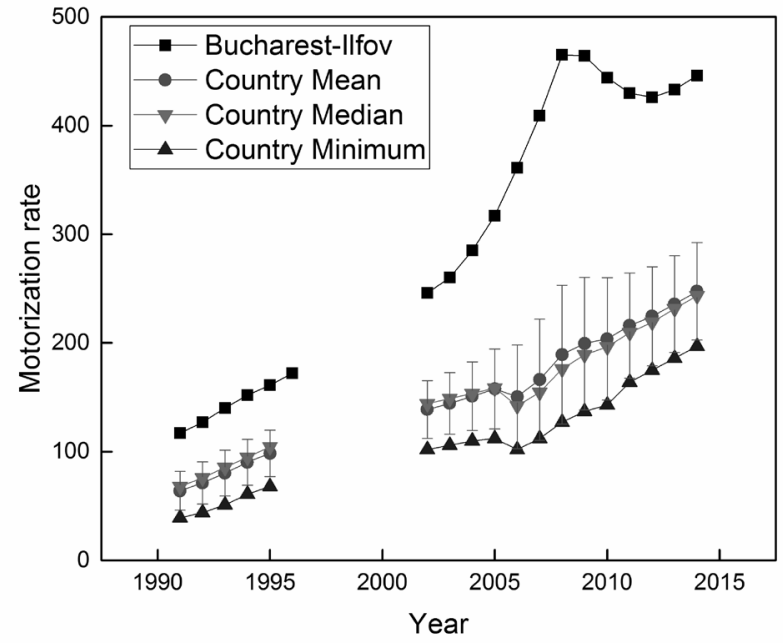

Figure 9: Change in the motorization rate during the transition period

Source: Toșa, Miwa, and Morikawa (2015)

In a comprehensive urban transport study financed by the Japan International Cooperation Agency (JICA) in 1998, the road network in Bucharest was measured to be about 1,841 km long, reaching $1,936 \mathrm{~km}$ in 2013 (INS). Compared to other cities around the world, the road density in Bucharest seems to be comparatively low. Taking its road area ratio, i.e. the road area per unit of urban area, as a benchmark, Bucharest only reaches the $12.7 \%$ threshold, compared to Paris (20.0\%), London (16.6\%), or Tokyo's 23 wards (15.2\%). Nevertheless, this figure is somewhat similar to Vienna (cf. JICA, 2000). This leads us to conclude that the roads in Bucharest are comparatively wide, but that the density of the road network, which amounts to approximately $9 \mathrm{~km} / \mathrm{km}^{2}$, as a whole, is insufficient. However, for better measurements, as well as for establishing correlations between automobile ownership levels and road network supply, Hayashi (1996) recommends the use of another indicator, namely, road network length per car. Figure 10 shows the relationship between the evolution of the motorization rate of Bucharest and the road network length, to emphasize the impact of motorization growth over time.

It is also worth mentioning that automobile density is also influenced by the width of roads. Hence, one could more accurately measure this indicator using vehicles/lane kilometers, but, unfortunately, no such data is available. 


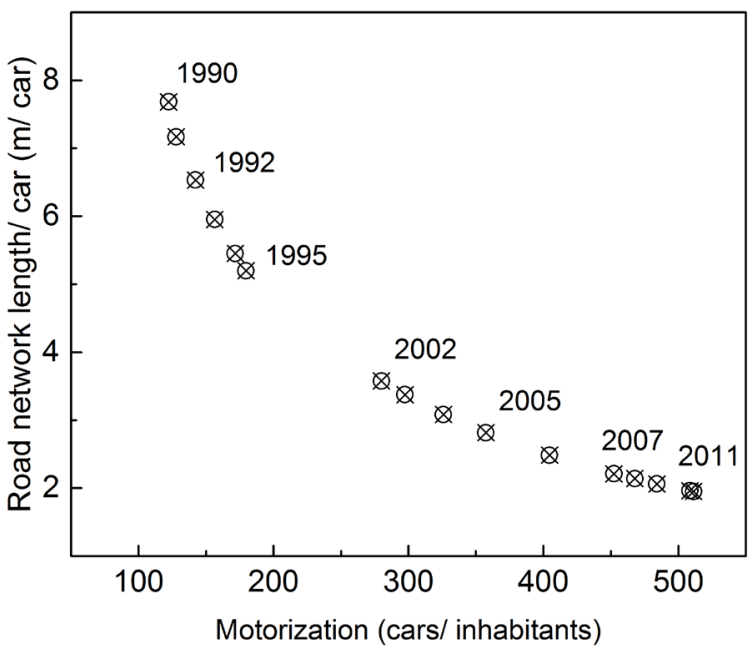

Figure 10: Motorization rate and road length per car in Bucharest

Source: Authors, based on INS data

To complement this information, in Table 2 we present data on modal split, drawn from travel surveys conducted in Bucharest in the years of 1998, 2007, and 2015. A modal shift has been recorded from public transport to private mobility, while non-motorized means of travel, such as walking and cycling, have decreased in use over time, because of worsening of traffic conditions and road safety. Additionally, Figure 11 reveals a continuous decrease of overall public transport ridership. In 1998, metro ridership amounted to some $9 \%$ of the total urban trips, the lowest since 1990, accounting for $17 \%$ of the total public transport trips. At that time, bus and tram accounted each for some $36 \%$, while the trolleybus registered the lowest ridership among public transport modes, with around 11\% (JICA, 2000). Compared to the JICA study, the survey conducted for the Bucharest Transport Master Plan (WSP Group, 2007), showed that the share of metro trips accounted for $16 \%$ of the total. One reason for the growth in metro ridership in Bucharest may be the introduction of the magnetic card system in 2000. After six years, the ticketing system was integrated with the public ground transport (no longer available during the delivery of SUMP Bucharest in 2015), which was even more beneficial to metro ridership, but was to the detriment of other public transport modes.

Table 2: Evolution of modal split and average speeds

\begin{tabular}{|c|c|c|c|c|c|c|c|c|}
\hline \multirow[t]{2}{*}{ Study (Year) } & \multirow[t]{2}{*}{ Measure } & \multirow[t]{2}{*}{ Automobile } & \multicolumn{4}{|c|}{ Public Transport } & \multirow[t]{2}{*}{ Non- } & \multirow[t]{2}{*}{ Other } \\
\hline & & & Bus & Trolleybus & Tram & Metro & & \\
\hline \multirow[t]{2}{*}{ JICA (1998) } & Share \% & 28 & 18 & 6 & 19 & 9 & - & 20 \\
\hline & Av. Speed & $27.6^{1}$ & 19.8 & 13.7 & 14.5 & $36^{2}$ & - & - \\
\hline \multirow{2}{*}{$\begin{array}{l}\text { Bucharest Transport } \\
\text { Master Plan (2007) }\end{array}$} & Share & 23 & 16 & 2 & 16 & 16 & 22 & 5 \\
\hline & Av. Speed & - & 14.5 & 11.9 & 14.6 & $33^{2}$ & - & - \\
\hline \multirow{2}{*}{$\begin{array}{l}\text { SUMP Bucharest } \\
(2015)\end{array}$} & Share & 38 & 12 & 1 & 4 & 10 & 33 & 2 \\
\hline & Av. Speed & 24.2 & 13.7 & 11.9 & - & $35^{2}$ & - & - \\
\hline
\end{tabular}

peak hour, Bucharest inner ring peak hour data

${ }^{2}$ scheduled speed

Source: JICA (2000), Avensa Consulting \& ROM Transportation Engineering (2015), and WSP Group (2007) 


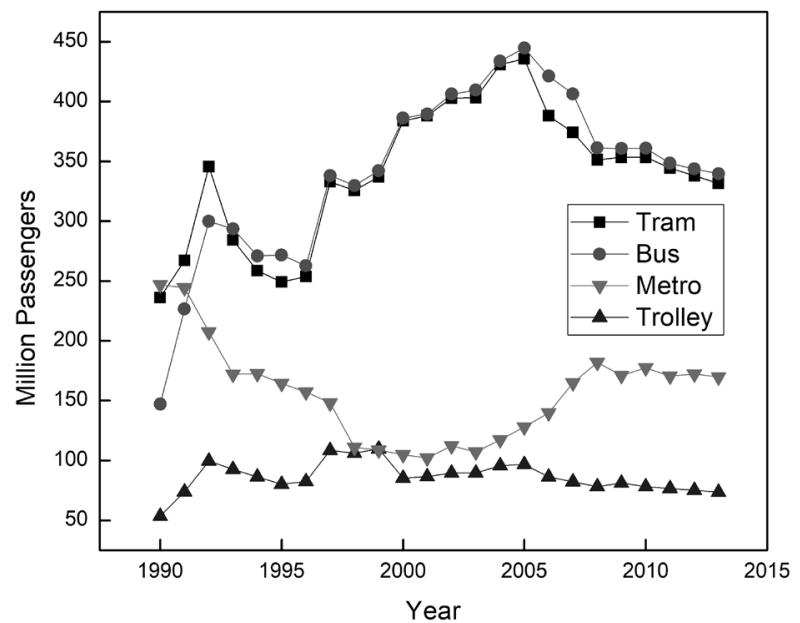

Figure 11: Public transport modes ridership evolution in Bucharest Source: INS

Against this background, rush-hour traffic congestion is a major concern, affecting millions of people worldwide and leading to financial losses and adverse effects on the environment (Cohn, Kools, \& Mieth, 2012). Schafer et al. (2011) efficiently used TomTom probe vehicle data for empirical research into traffic. Online reports state that Bucharest is ranked as the fifth most congested city worldwide and the first in Europe in the year 2016. Hyman and Mayhew (2002) state that public transport is among the solutions to solve the urban traffic congestion problem. However, when it comes to Bucharest, modal shifts over time are the result of a gradual orientation towards private car use. Increased car ownership has decreased the level of service for ground public transport, because there is no dedicated right of way network available (cf. Table 2). In addition, Table 3 displays the characteristics of the public transport system in terms of network length for the modes available (Taylor, 2006). We find it remarkable that the tram network, extensive as it is, and historically dense within the metropolitan area (Avensa Consulting \& ROM Transportation Engineering, 2015), is constantly identified as duplicating or competing with the metro (JICA, 2000).

Table 3: Characteristics of the Bucharest public transport network

\begin{tabular}{|l|c|}
\hline Attributes & Length \\
\hline City road network $[\mathrm{km}]$ & 1936 \\
\hline Total bicycle network $[\mathrm{km}]$ & 5 \\
\hline City tram network $[\mathrm{km}](\%$ with right of way) & $292(64 \%)$ \\
\hline City metro network $[\mathrm{km}]$ & 69 \\
\hline City bus network $[\mathrm{km}](\%$ segregated) & $1004(0 \%)$ \\
\hline
\end{tabular}

Source: Taylor (2006)

Furthermore, in a recent study on car ownership modeling and forecasting for Romania's major administrative areas (Toșa, Miwa, \& Morikawa, 2015), GDP was shown to be a contributing factor for the growth in motorization rate. According to the targeted motorization rate of other European metropolises and the potential for further economic growth, the automobile fleet of Bucharest will reach saturation around the year 2035. However, this study did not take any other variables into account. Considering 
the data exhibited within this section, we raise the concern of the discharge of the motorization rate from the Bucharest area towards Ilfov (cf. Figure 12). Hence, even though it is questionable whether the motorization growth rate will slow down within the municipality of Bucharest, we need to point out that the 2008 financial crisis definitely tempered the growth of car ownership. Hence, when analyzing car ownership dynamics within Bucharest and Ilfov, correlated to GRP, we can identify an increase in the motorization of the outskirts, and a concomitant decrease within the city of Bucharest. Surprisingly enough, the economic recovery in terms of GRP that started in 2009 in Bucharest, unexpectedly led to a decrease in the motorization rate, but brought an increase in Ilfov, even though its GRP decreased.

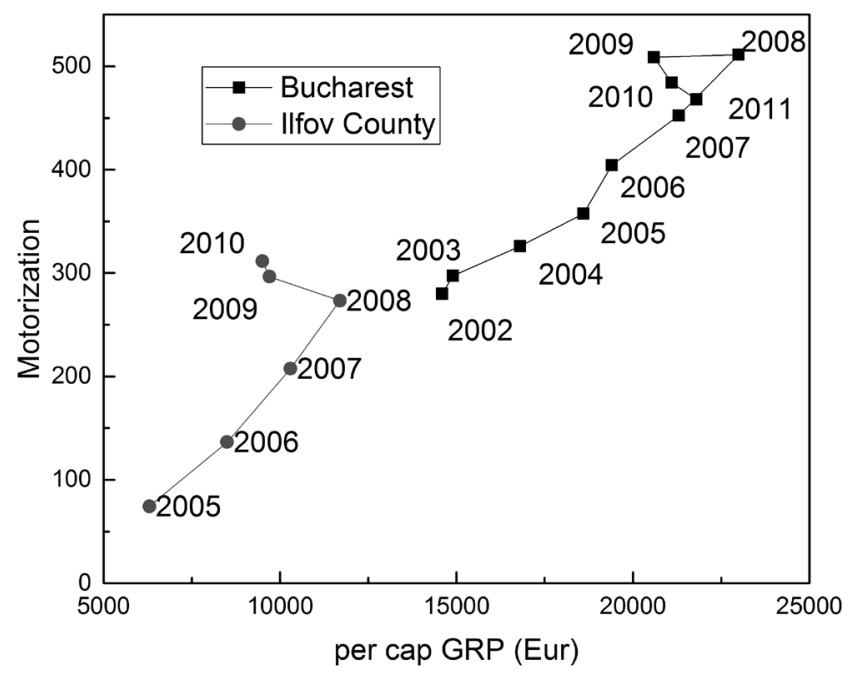

Figure 12: Car ownership dynamics in Bucharest and Ilfov

Source: Authors, based on INS data

This trend is consistent with the population dynamics of Figure 5, which showed the out-of-thecity migration between 2002 and 2011. Even if we assume that further increases in GRP might encourage people to migrate towards Ilfov, this will lead to an increase in car ownership and more dispersed residential development. Further analysis could shed light on this phenomenon and contribute to the understanding of transport geography in post-socialist developing metropolises.

\section{Discussion}

Without a doubt, the diffusion of economic well-being within the Bucharest-Ilfov Metropolitan Area has led to a corrosive process of urban sprawl, which came hand in hand with ever-increasing levels of motorization. Longer trips became the norm and damage to the environment quickly became visible. We noted earlier how population exposure to a political system change towards a competitive market can lead to the advancement of human capital, bringing added value to businesses and contributing to GDP growth. However, as the prevailing levels of expertise within public authorities did not permit more than limited interventions in transport policies, based on the 'predict and provide' philosophy for car traffic, the refinement of social capital allowed several groups to repeatedly call for system reform through the participation of civic society in administrative decisions (Kanters, 2014).

Despite societal wealth, the Romanian transition period has manifested itself through population contraction and ageing. Nonetheless, the scarcity of studies dedicated to the 25 years of transition poses challenges and difficulties for policy makers. We believe such studies to become a matter of research in- 
terest in the years to follow, as they are crucial for issuing relevant forecasts and formulating appropriate planning policies.

Clearly, residential migration trends, modal share shift towards privately-owned cars, and the decrease in public transport ridership, place Bucharest-Ilfov Metropolitan Area on a development path similar to those experienced by other Western European cities. The Compact city concept (Burton, Jenks, \& Williams, 1996; Headicar, 2003) is widely promoted as a measure to reduce the need for travel and, implicitly, the per capita carbon dioxide $\left(\mathrm{CO}^{2}\right)$ emissions arising from transport. From a land-use planning perspective, the maintenance of a well-controlled city boundary through land recycling in the built-up areas would severely limit 'greenfield' developments, thereby contributing significantly to a more efficient urban form.

From a transportation perspective, proper policies for public transport, aimed at providing an alternative to personal motorized mobility should be adopted by supplying mobility without large infrastructure costs. As mentioned earlier, the growth in motorization that characterizes Bucharest seems to have lost momentum, but the possibility of increase still exists within the county of Ilfov. Hence, in order to achieve a growing modal share of public transport, authorities should improve the accessibility of stations and the level of service for the outskirts of Bucharest. At the same time, the characteristics of the road network discussed above might support the extension of segregated public transport lanes to connect the suburbs with the city center. Superior travel speeds and smaller headway between vehicles may improve the quality of public transport and produce a shift towards this mode.

To countervail the dominating logic obedient to the automobile that has pervaded planning decisions during the entire transition period, policy makers should focus on the needs and habits of the individual when designing transport systems. Griffiths, Richardson, and Lee-Gosselin (2000) agree upon the immediate need to design and conduct municipal and countywide travel surveys that study household and transport needs, household behavior, while at the same time to forecast population dynamics within metropolitan areas.

In addition, historical comparisons of developing metropolises (Hayashi, 1996) could allow for more relevant scenario formulations that would better accommodate future and more sustainable development paths, while at the same time ensuring a more pleasant living environment. We therefore intend to raise awareness of this topic, by further acknowledging the need for in-depth comparisons among former socialist cities. Future debates should also refer to the model each of the post-socialist cities has followed, be it the North American, the Western European, or any other model.

Another method that is widely adopted implies collecting data from successive events in one's life for the analysis of long-term social and land-use changes (Blossfeld \& Rohwer, 2002). This method is also known as the life-course approach. This may offer complete and consistent information on residential mobility and associated travel behavior of the residents within a wider area, while accounting for the socio-economic and political context. We believe that such a study would result in sound regional planning policies to facilitate the gradual achievement of a self-sufficient urban environment.

\section{Acknowledgments}

Corresponding author acknowledges financial support from Kakenhi Grant-in-Aid for Scientific Research (grant numbers 26 04707 and 15F14707), awarded by Japan Society for the Promotion of Science (JSPS).

Part of this paper was presented at the 14th International Conference on Mobility and Transport for Elderly and Disabled Persons (TRANSED), held in Lisbon, Portugal, July 2015. Corresponding author gratefully acknowledges the guidance and assistance in initial draft preparation given by Professor Yoshitsugu Hayashi. 


\section{References}

Avensa Consulting, \& ROM Transportation Engineering. (2015). Planul de mobilitate urbană durabilă 2016-2030 Regiunea București Ilfov. Retrieved from http://www.pmb.ro/servicii/transporturi_drumuri/docs/planul_de_mobilitate_durabila_2016-2030.pdf

Balint, B. (2013). The role of social capital in avoiding over-education (English version). Romanian Journal of Sociology, 1, 101-126.

Barro, R. J. (2001). Human capital and growth. The American Economic Review, 91(2), 12-17.

Barro, R. J., \& Sala-i-Martin, X. (2004). Economic growth, second edition. Cambridge, MA: MIT Press.

Bere, R. C., Otoiu, A., \& Bucerzan, I. (2014). Determinants of economic growth in cities acting as growth poles in regions from Romania. Procedia Economics and Finance, 10, 357-365.

Bertaud, A. (2006). The spatial structures of Central and Eastern European cities. In S. Tsenkova \& Z. Nedovic-Budic (eds.) The urban mosaic of post-socialist Europe, 91-110. Heidelberg, Germany: Physica-Verlag.

Benedek, J. (2015). Spatial differentiation and core-periphery structures in Romania. Eastern Journal of European Studies, 6(1), 49-61.

Benedek, J., \& Veress, N. C. (2013). Economic disparities and changes in the convergence of the Romanian NUTS 2 and NUTS 3 Regions, Romanian Review of Regional Studies, 9(1), 85-90.

Blossfeld, H. P., Rohwer, G. (2002). Techniques of event history modeling: New approaches to casual analysis. Mahwah, NJ: Lawrence Erlbaum Associate.

Botzen, K. (2016). Social capital and economic well-being in Germany's regions: An exploratory spatial analysis. Region, 3(1), 1-24.

Boquet, Y. (2009, August). Can Western mobility solutions apply to East Asia's cities? In Proceedings of the 10th Asian Urbanization Conference, Hong Kong, August 16-19 (pp. CD-ROM).

Buckley, R. M., \& Mini, F. (2000). From commisars to mayors: Cities in transition economies. Washington, DC: The World Bank. Retrieved from http://documents.worldbank.org/curated/ en/2000/09/693201/commissars-mayors-cities-transition-economies

Burton, E., Jenks, M., \& Williams, K. (Eds.) (1996). The compact city: A sustainable urban form? Abingdon, UK: Routledge.

Cervero, R., \& Kockelman, K. (1997). Travel demand and the 3Ds: Density, diversity, and design. Transportation Research Part D: Transport and Environment, 2(3), 199-219.

Chelcea, L. (2006). Marginal groups in central places: Gentrification, property rights and post socialist primitive accumulation (Bucharest, Romania). In G. Enyedi \& Z. Kovács (Eds.) Social changes and social sustainability in historical urban centers: The case of Central Europe. Pécs, Hungary: Centre for Regional Studies of Hungarian Academy of Sciences.

Ciumara, T. (2014). Baby boomers and the Romanian financial system. Hyperion Economic Journal, 2(1), 12-17.

Cohn, N., Kools, E., \& Mieth, P. (2012). The TomTom congestion index. Presented at the 19th ITS World Congress, Vienna, Austria, October 22-26.

Cook, B. A. (Ed.). (2001). Europe since 1945: An encyclopedia (Vol. 2). Abingdon, UK: Taylor \& Francis.

Coughlin, J., \& Lacombe, A. (1997). Ten myths about transportation for the elderly. Transportation Quarterly, 51(1), 91-100.

Coughlin, J., \& Tompkins, C. (2009). Demographics, destiny, and anticipating the future of the transportation system. Public Works Management \& Policy, 13(4), 284-287.

Crass, M. (2002). Implementing sustainable urban travel policies. Public Transport International, 51(1), $24-25$. 
Doi, K., \& Kurokawa, K. (2001). Integrated design of LUCC policies and environmental simulation in Metro Manila. In Proceedings of LUCC Symposium (Vol. 1, p. 11).

Dostie, B., \& Sahn, D. E. (2006). Labor market dynamics in Romania during a period of economic liberalization. (IZA discussion papers). Retrieved from https://www.econstor.eu/bitstream/10419/33815/1/541557963.pdf

European Commission. (1996). The Citizens' Network. Fulfilling the potential of public passenger transport in Europe. Retrieved from ftp://ftp.cordis.europa.eu/pub/transport/docs/citizens_network_en.pdf

European Commission. (2001). White paper-European transport policy for 2010: Time to decide. Retrieved from http://ec.europa.eu/transport/themes/strategies/doc/2001_white_paper/lb_ com_2001_0370_en.pdf

European Commission (2007). Green paper-Towards a new culture for urban mobility. Retrieved from http://eur-lex.europa.eu/legal-content/EN/TXT/PDF/?uri=CELEX:52007DC0551\&from= EN

European Commission (2013). Together towards competitive and resource-efficient urban mobility. Retrieved from http://ec.europa.eu/transport/themes/urban/doc/ump/com(2013)913_en.pdf

Enyedi, G. (1996). Urbanization under socialism. In G. Andrusz, M. Harloe, \& I. Szelényi (Eds.), Cities after socialism: Urban and regional change and conflict in post-socialist societies. Oxford, UK: Blackwell Publishers Ltd. doi: 10.1002/9780470712733.ch4

Grădinaru, S. R., Iojă, C. I., Pătru-Stupariu, I., Niţă, M. R., Gavrilidis, A. A., \& Cârstea, E. M. (2013). Land abandonment changes between 2005 and 2008 in Bucharest city. Procedia Technology, 8, 536 539.

Gallagher, T. (2005). Theft of a nation. Romania since communism. London: Hurst \& Co.

Gallagher, T. (2009). Romania and the European Union. How the weak vanquished the strong. Manchester, England: Manchester University Press.

Griffiths, R., Richardson, A. J., \& Lee-Gosselin, M. E. (2000). Travel surveys, transportation in the new millennium. Washington, DC: Transportation Research Board. Retrieved from http://gulliver. trb. org/publications/millennium/00135.pdf

Grigorescu, I., Mitrica, B., Kucsicsa, G., Popovici, E. A., Dumitrascu, M., \& Cuculici, R. (2012). Postcommunist land use changes related to urban sprawl in the Romanian metropolitan areas. Human Geographies, 6(1), 35-46. doi:10.5719/hgeo.2012.61.35

Hamilton, F. I., Andrews, K. D., \& Pichler-Milanović, N. (Eds.). (2005). Transformation of cities in Central and Eastern Europe: Towards globalization. Tokyo: United Nations University Press.

Hayashi, Y. (1996). Economic development and its influence on the environment: Urbanization, infrastructure and land-use planning systems. In Y. Hayashi \& J. Roy (Eds.), Transport, land use and the environment (pp. 3-25). New York: Springer US. doi: 10.1007/978-1-4757-2475-2

Hyman, G., \& Mayhew, L. (2002). Optimizing the benefits of urban road user charging. Transport Policy, 9(3), 189-207.

Headicar, P. (2003). The contribution of land-use planning to reducing traffic growth: The English experience. European Journal of Transport and Infrastructure Research, 3(2), 137-154.

Hegedüs, J. (2008). The future of re-invented/post-socialist cities in Europe: A reflection on the state of European cities report (2007). Urban Research \& Practice, 1(3), 311-318.

Hegedüs, J., Tosics, I., \& Mayo, S. K. (1996). Transition of the housing sector in the East-Central European countries. Review of Urban and Regional Development Studies, 8(2), 101-136. doi: 10.1111/j.1467-940X.1996.tb00113.x

Ionescu-Heroiu, M., Neagu, M., Taralunga, N., Ortiz, P., Petrovici, N., Moldovan, C., \& Panescu, E. 
(2013a). Romania —enhanced spatial planning as a precondition for sustainable urban development. Washington DC: World Bank Group. Retrieved from http://documents.worldbank.org/curated/en/2013/12/19151611/romania-enhanced-spatial-planning-precondition-sustainable-urbandevelopment-vol-1-2-raport-complet

Ionescu-Heroiu, M., Burduja, S. I., Sandu, D., Cojocaru, S., Blankespoor, B., Iorga, E., Moretti, E., Moldovan, C., Man, T., Rus, R. \& van der Weide, R. (2013b). Romania-competitive cities: Reshaping the economic geography of Romania. Romania regional development program. Washington DC: World Bank Group. Retrieved from http://documents. worldbank. org/curated/ en/2013/12/19060303/romaniacompetitive-cities-reshaping-economic-geography-romania

Irwin, E. G., Isserman, A. M., Kilkenny, M., \& Partridge, M. D. (2010). A century of research on rural development and regional issues. American Journal of Agricultural Economics 92(2), 522-553.

Jemna, D. V., Pintilescu, C., \& Turturean, C. (2010). Population in Romania within the united Europe. Analele Stiintifice ale Universitatii "Alexandru Ioan Cuza" din Iasi-Stiinte Economice, 329-340.

Jensen, M. (1999). Passion and heart in transport—a sociological analysis on transport behavior. Transport Policy, 6(1), 19-33.

JICA. (2000). The comprehensive urban transport study of Bucharest city and its metropolitan area in the Republic of Romania (final report). Retrieved from http://www.srl.de/dateien/dokumente/de/the_ comprehensive_urban_transport_study_of_bucarest_and_its_metropolitain_area_in_the_republic_of_romania_-_teil_1.pdf

Judge, E., \& Kaminski, R. (1996). Recent developments in Polish transport policy: Conflicts between growth and sustainability. In Pan-European transport issues: Proceedings of seminar A held at the 24th European Transport Forum, Brunel University, England, September 2-6, 1996. Vol P401.

Kanters, R. (2014). The critical mass expands the bike culture in Bucharest (Romania). Retrieved from http://www.eltis.org/discover/news/critical-mass-expands-bike-culture-bucharest-romania-0

Kenworthy, J. R., \& Laube, F. B. (1999). Patterns of automobile dependence in cities: An international overview of key physical and economic dimensions with some implications for urban policy. Transportation Research Part A: Policy and Practice, 33(7), 691-723.

Kloas, J., Kuhfeld, H., \& Kunert, U. (1998). Region Berlin: Langfristig mehr Verkehr, aber weniger Fahrgäste in Bussen und Bahnen. DIWWochenbericht, 65(14), 258-263.

Kornai, J. (1992). The socialist system: The political economy of communism. Oxford, UK: Oxford University Press. doi: 10.1093/0198287763.001.0001

Kubík, R. (2010). Looking for the right human capital proxy. Review of Economic Perspectives, 10(2), $61-70$.

Mincer, J. (1984). Human capital and economic growth. Economics of Education Review, 3(3), 195-205.

Miyamoto, K., Acharya, S. R., Aziz, M. A., Cusset, J. M., Fwa, T. F., Gerçek, H., ... \& Lee, S. (2004). Transport-environment issues and countermeasures in various metropolises. In Urban transport and the environment: An international perspective (pp. 253-402). Amsterdam: Elsevier Science Ltd.

Mulder, K., Costanza, R., \& Erickson, J. (2006). The contribution of built, human, social and natural capital to quality of life in intentional and unintentional communities. Ecological Economics, 59(1), $13-23$.

Nae, M., \& Turnock, D. (2011). The new Bucharest: Two decades of restructuring. Cities, 28(2), 206219.

Newman, P. W., \& Kenworthy, J. R. (1991). Transport and urban form in thirty-two of the world's principal cities. Transport Reviews, 11(3), 249-272.

Ofrim, A. (2013). O scurtă istorie a comunismului din România. Retrieved from http://dilemaveche. ro/sectiune/tema-saptamanii/articol/o-scurta-istorie-a-comunismului-din-romania 
Petre, I. (2008). The emergence of a new peri-urban pattern in Romania. Romanian Journal of Sociology, $1(2), 133-144$.

Pop-Eleches, C. (2006). The impact of an abortion ban on socioeconomic outcomes of children: Evidence from Romania. Journal of Political Economy, 114(4), 744-773.

Popescu, C. C. (2012). The deterioration of the economic environment and the regional redistribution of the human capital stock in Romania. Procedia-Social and Behavioral Sciences, 62, 285-289.

QGIS Development Team. (2013). QGIS geographic information system. Open Source Geospatial Foundation Project. Retrieved from http://qgis.osgeo.org

Rodrigue, J. P., Comtois, C., \& Slack, B. (2017). The geography of transport systems. New York: Routledge.

Riboud, M. (2016). Investing in inclusive human development. Global Journal of Emerging Market Economies, 8(2), 168-200.

Rosenbloom, S. (2010). How adult children in the UK and the US view the driving cessation of their parents. Is a policy window opening? Journal of Transport Geography, 18(5), 634-641.

Ryser, L., \& Halseth, G. (2012). Resolving mobility constraints impeding rural seniors' access to regionalized services. Journal of Aging \& Social Policy, 24(3), 328-344.

Schafer, R. P., Lorkowski, S., Witte, N., Palmer, J., Rehborn, H., \& Kerner, B. S. (2011). A Study of TomTom's probe vehicle data with three-phase traffic theory. Traffic Engineering and Control, 52(2011), 225-230.

Schwanen, T. (2002). Urban form and commuting behavior: A cross-European perspective. Tijdschrift Voor Economische en Sociale Geografie, 93(3), 336-343.

Scrieciu, S. S. (2011). Socioeconomic and environmental impacts on agriculture in the new Europe: Postcommunist transition and accession to the European Union. Abingdon, UK: Taylor \& Francis eBooks. doi: $10.4324 / 9780203828502$

Simion, G., \& Nistor, C. (2012). Spatial structure changes inside post-communist capital city of Bucharest. Human Geographies, 6(1), 79-89.

Șoaită, A. M. (2014). Overcrowding and 'underoccupancy' in Romania: A case study of housing inequality. Environment and Planning A, 46(1), 203-221. doi: 10.1068/a45718

Stanilov K. (2007) Housing trends in Central and Eastern European cities during and after the period of transition. In K. Stanilov (Ed.) The post-socialist city (pp. 173-190). Dordrecht, Netherlands: Springer. doi: 10.1007/978-1-4020-6053-3_9

Suditu, B., Dumitrache, L., Vîrdol, D., \& Vâlceanu, D. G. (2014). New trajectories of post-socialist residential mobility in Bucharest. Human Geographies, 8(1), 75-82. doi:10.5719/hgeo.2014.81.75

Taniguchi, M., Murakawa, T., \& Morita, T. (1999). Analysis on relationship between urban characters and car usage based on personal trip data. Journal of the City Planning Institute ofJapan, 34, 967-972.

Taylor, N. (2006). The urban transport benchmarking initiative year three (final report). European Commission. Retrieved from http://www.velomondial.net/UserFiles/File/WWW-transportbenchmarksorg-UTB3-A0-FINAL-REPORT.pdf

Toşa, C, Miwa, \& T., Morikawa, T. (2015). Modelling and forecasting car ownership in Romania's counties using bass diffusion model. Presented at the European Transport Conference, Frankfurt, Germany, September 28-30.

Tsenkova, S., \& Nedovic-Budic, Z. (Eds.). (2006). The urban mosaic of post-socialist Europe: Space, institutions and policy. Heidelberg, Germany: Physica-Verlag. doi: 10.1007/3-7908-1727-9

Turnock, D. (1990). City profile: Bucharest. Cities, 7(2), 107-118.

van den Berg, P., Arentze, T., \& Timmermans, H. (2011). Estimating social travel demand of senior citizens in the Netherlands. Journal of Transport Geography, 19(2), 323-331. 
van de Coevering, P., \& Schwanen, T. (2006). Re-evaluating the impact of urban form on travel patterns in Europe and North-America. Transport policy, 13(3), 229-239.

Vemuri, A. W., \& Costanza, R. (2006). The role of human, social, built, and natural capital in explaining life satisfaction at the country level: Toward a national well-being index (NWI). Ecological Economics, 58(1), 119-133.

Wegener, M. (1996). Reduction of $\mathrm{CO}^{2}$ emissions of transport by reorganization of urban activities. In Transport, land-use and the environment (pp. 103-124). New York: Springer US.

Wegener, M. (2004). Overview of land use transport models. In D. A. Hensher, K. J. Button, K. E. Haynes, P. R. Stopher (Eds.), Handbook of transport geography and spatial systems (Handbooks in Transport, Volume 5) (pp. 127-146). Bingley, UK: Emerald Group Publishing Limited.

Wolf, W. (1994). Berlin-Weltstadt ohne auto? Verkehrsgeschichte 1848-2015. Frankfurt: Neuer ISP-Verlag. WSP Group. (2007). Master plan general pentru transport urban-Bucuresti, sibiu si ploiesti - raport final Bucuresti. Retrieved from http://www.pmb.ro/institutii/cgmb/dezb_publica/sedinte/proiecte_2008/31_01_2008.pdf 